\title{
CD36-mediated activation of endothelial cell apoptosis by an N-terminal recombinant fragment of thrombospondin-2 inhibits breast cancer growth and metastasis in vivo
}

\author{
Manuel Koch • Fadi Hussein • Andreas Woeste • \\ Carsten Gründker • Karl Frontzek • \\ Günter Emons • Thomas Hawighorst
}

Received: 16 May 2010/ Accepted: 20 July 2010/Published online: 17 August 2010

(C) Springer Science+Business Media, LLC. 2010

\begin{abstract}
Thus far the clinical benefits seen in breast cancer patients treated with drugs targeting the vascular endothelial growth factor (VEGF) pathway are only modest. Consequently, additional antiangiogenic approaches for treatment of breast cancer need to be investigated. Thrombospondin-2 (TSP-2) has been shown to inhibit tumor growth and angiogenesis with a greater potency than the related molecule TSP-1. The systemic effects of TSP-2 on tumor metastasis and the underlying molecular mechanisms of the antiangiogenic activity of TSP-2 have remained poorly understood. We generated a recombinant fusion protein consisting of the N-terminal region of TSP-2 and the IgG-Fc1 fragment (N-TSP2-Fc) and could demonstrate that the antiangiogenic activity of N-TSP2-Fc is dependent on the CD36 receptor. We found that N-TSP2-Fc inhibited VEGF-induced tube formation of human dermal microvascular endothelial cells (HDMEC) on matrigel in vitro and that concurrent incubation of anti-CD36 antibody with $\mathrm{N}-\mathrm{TSP} 2-\mathrm{Fc}$ resulted in tube formation that was comparable
\end{abstract}

Manuel Koch and Fadi Hussein contributed equally to this study.

Electronic supplementary material The online version of this article (doi:10.1007/s10549-010-1085-7) contains supplementary material, which is available to authorized users.

M. Koch · A. Woeste

Institute for Oral and Musculoskeletal Biology,

Department of Dermatology, Center for Biochemistry,

Center for Molecular Medicine Cologne, Medical Faculty,

University of Cologne, 50931 Cologne, Germany

F. Hussein · C. Gründker · K. Frontzek · G. Emons ·

T. Hawighorst $(\bowtie)$

Department of Gynecology and Obstetrics, University Medical

Center Göttingen, Georg-August-University Göttingen,

37075 Göttingen, Germany

e-mail: thomas.hawighorst@med.uni-goettingen.de to untreated control. N-TSP2-Fc potently induced apoptosis of HDMEC in vitro in a CD36-dependent manner. Moreover, we could demonstrate a CD36 receptor-mediated loss of mitochondrial membrane potential and activation of caspase-3 in HDMEC in vitro. Daily intraperitoneal injections of N-TSP2-Fc resulted in a significant inhibition of the growth of human MDA-MB-435 and MDA-MB-231 tumor cells grown in the mammary gland of immunodeficient nude mice and in reduced tumor vascularization. Finally, increased serum concentrations of N-TSP2-Fc significantly inhibited regional metastasis to lymph nodes and distant metastasis to lung as shown by quantitative real-time alu PCR. These results identify N-TSP2-Fc as a potent systemic inhibitor of tumor metastasis and provide strong evidence for an important role of the CD36 receptor in mediating the antiangiogenic activity of TSP-2.

Keywords Breast cancer - Thrombospondin-2 - CD36 . Metastasis · Angiogenesis

\section{Introduction}

There is large amount of evidence that tumor growth is dependent on angiogenesis $[8,15,16]$. Clinically, proof of concept has begun with the recent regulatory approvals of three antiangiogenic therapies targeting the vascular endothelial growth factor (VEGF) pathway. Despite early benefits seen in breast cancer patients treated with antiVEGF therapies [29], enduring efficacy with regard to survival benefits is relatively modest [23]. In addition, recent data provided strong evidence that tumors may escape or become resistant to the antiangiogenic effects of blocking the VEGF signaling pathway $[14,36]$. Therefore, additional antiangiogenic approaches need to be evaluated. 
Two members of the thrombospondin (TSP) family [1, 22], TSP-1 and TSP-2, are important naturally occurring angiogenesis inhibitors. Both proteins were shown to have potent antiangiogenic activity by inhibiting endothelial cell proliferation, migration, and tube formation in response to multiple angiogenic stimuli $[27,50]$, and by inhibiting angiogenic responses in a number of in vivo models [1]. The antiangiogenic activity of TSP-1 was localized to the properdin-like type I repeats, also called thrombospondin structural homology repeats (TSR), in the N-terminal domain of TSP-1 [20]. In contrast to TSP-1, the molecular mechanism of the antiangiogenic activity of TSP-2 has not been as well studied. Since it has been reported that TSP-2 is more effective in inhibiting tumor growth and angiogenesis than TSP-1 [25] [28] [45], we generated a recombinant fusion protein consisting of the $\mathrm{N}$-terminal region of TSP-2 and an IgG-Fc1 fragment (N-TSP2-Fc). N-TSP2-Fc contained the procollagen homology domain as well as three type I repeats of TSP-2. Here, we report that recombinant N-TSP2-Fc induced apoptosis of endothelial cells by CD36 receptor-mediated loss of mitochondrial membrane potential and activation of caspase-3. In contrast to the majority of experimental antiangiogenic studies that only focused on the effects on primary tumor growth, with much less attention on metastasis, we provide strong evidence that N-TSP2-Fc significantly inhibited tumor growth of xenotransplanted MDA-MB-435 and MDA-MB-231 breast cancer cells and both lymph node as well as lung metastasis of MDA-MB-435 tumor cells grown as xenotransplants in the mammary gland of nude mice.

\section{Materials and methods}

\section{Cell lines and culture}

Human MDA-MB-435 and MDA-MB-231 breast cancer cells were obtained from ATCC and maintained in DMEM medium (Invitrogen) containing 10\% FCS, $4.5 \mathrm{mg} / \mathrm{ml}$ glucose, $2 \mathrm{mM}$ L-glutamine, $100 \mathrm{units} / \mathrm{ml}$ penicillin $\mathrm{G}$, and $100 \mu \mathrm{g} / \mathrm{ml}$ streptomycin. Human 293-EBNA (Epstein-Barr virus nuclear antigen) cells (Invitrogen) were maintained in DMEM/F12 medium (Invitrogen) containing 10\% FCS, 15 mM HEPES, $1.0 \mu \mathrm{g} / \mathrm{ml}$ puromycin, 100 units $/ \mathrm{ml}$ penicillin G, $100 \mu \mathrm{g} / \mathrm{ml}$ streptomycin, and $0.25 \mu \mathrm{g} / \mathrm{ml}$ fungizone, amphotericin B (Invitrogen). Human dermal microvascular endothelial cells (HDMEC) from Promocell (Heidelberg, Germany) were cultured in ECGM-MV medium (Promocell) containing fetal calf serum $(0.05 \mathrm{ml} / \mathrm{ml})$, endothelial cell growth supplement $(0.004 \mathrm{ml} / \mathrm{ml})$, recombinant human epidermal growth factor (10 ng/ml), heparin $(22.5 \mu \mathrm{g} / \mathrm{ml})$, hydrocortisone $(1 \mu \mathrm{g} / \mathrm{ml})$, and phenol red $(0.62 \mathrm{ng} / \mathrm{ml})$ supplemented with $50 \mathrm{U} / \mathrm{ml}$ penicillin and $50 \mu \mathrm{g} / \mathrm{ml}$ streptomycin.

\section{Cell transfection}

The coding sequences of the N-terminal region of TSP-2 (aa 18-550 of human TSP-2) and the Fc region of human IgG1 (hinge and $\mathrm{CH}^{\prime \prime}$ and $\mathrm{CH} 3$ domains) were obtained by PCR and cloned into the the NheI and BamHI sites of a modified pCEP4 expression vector [24] that contains a cytomegalovirus enhancer/promoter, the EBNA-1 gene, and a puromycin selection cassette. Human 293-EBNA cells were stably transfected with the expression vector using the Fugene transfection reagent (Roche).

Purification of recombinant N-TSP2-Fc

The secreted fusion protein was purified from serum-free culture medium by using affinity chromatography with Protein G Sepharose (GE Healthcare Europe). The fusion protein was eluted with $0.1 \mathrm{M}$ glycine $(\mathrm{pH} 2.7)$, and each fraction was neutralized with $1 \mathrm{M}$ Tris- $\mathrm{HCl}(\mathrm{pH} 9.0)$. After dialysis the protein was stored at $-80^{\circ} \mathrm{C}$. The protein concentration was determined using the BCA protein assay kit (Pierce).

Tube formation assay

Twenty-four-well plates were coated with $300 \mu$ l Matrigel (BD Pharmingen) and incubated for $1 \mathrm{~h}$ at $37^{\circ} \mathrm{C}$. HDMEC $\left(1 \times 10^{5}\right.$ cells $)$ in ECGM-MV containing VEGF $(20 \mathrm{ng} / \mathrm{ml})$ were seeded into duplicate and observed at $12 \mathrm{~h}$. The formation of tube-like structures was analyzed using an Olympus IX51 microscope. Images were captured and computer-assisted analyses of tube length were performed using the Photoshop CS3 software (Adobe Systems).

\section{Apoptosis assay}

Primary HDMEC incubated in ECGM containing $\operatorname{VEGF}_{165}$ (R\&D Systems) at a concentration of $20 \mathrm{ng} / \mathrm{ml}$ were incubated with $40 \mu \mathrm{g} / \mathrm{ml}$ of N-TSP2-Fc with or without concurrent addition of $10 \mu \mathrm{g} / \mathrm{ml}$ of blocking CD36 antibody (Abcam) for $72 \mathrm{~h}$. Apoptosis was evaluated by using a procedure similar to that described by Nicoletti et al. [32]. Briefly, a pellet containing $1 \times 10^{6}$ HDMEC was gently resuspended in $500 \mathrm{ml}$ of hypotonic fluorochrome solution containing $0.1 \%$ Triton X-100 (Sigma), $0.1 \%$ sodium citrate, and $50 \mathrm{mg} / \mathrm{ml}$ propidium iodide (Sigma). After overnight incubation the cell suspensions were assayed by flow cytometry analysis of cellular DNA content on a FACSCalibur equipment (Becton-Dickinson Immunocytometry Systems) using CellQuest software (Becton-Dickinson Immunocytometry Systems). 
Mitochondrial membrane potential measurement

Human dermal microvascular endothelial cells cultured in ECGM containing VEGF $_{165}$ (R\&D Systems) at a concentration of $20 \mathrm{ng} / \mathrm{ml}$ were incubated with $40 \mu \mathrm{g} / \mathrm{ml}$ of N-TSP2-Fc with or without concurrent addition of $10 \mu \mathrm{g} / \mathrm{ml}$ of blocking CD36 antibody (Abcam) for $72 \mathrm{~h}$. The mitochondrial membrane potential was analyzed using the JC-1 mitochondrial membrane potential detection kit (Biotium).

Western blot analysis of caspase-3 activity

Human dermal microvascular endothelial cells were treated with N-TSP2-Fc (final concentration $40 \mu \mathrm{g} / \mathrm{ml}$ ) with or without concurrent addition of $10 \mu \mathrm{g} / \mathrm{ml}$ of blocking CD36 antibody (Abcam) for $72 \mathrm{~h}$. Cell lysates from HDMEC were separated on SDS/PAGE under reducing conditions and transferred to nitrocellulose membranes (HybonDECL, GE Healthcare Europe, Munich, Germany) and then immunoblotted with a rabbit anti-human active caspase-3 polyclonal antibody (BD Pharmingen). The specifically bound antibody was detected using the enhanced chemiluminescence kit (Millipore). The bands were analyzed using the Kodak image system (Kodak).

Tumorigenesis and metastasis assay

$2 \times 10^{6}$ MDA-MB-435 or $5 \times 10^{6}$ MDA-MB-231 breast cancer cells were injected bilaterally into the second mammary fat pads of athymic, female, 6-week-old NCR $\mathrm{nu} / \mathrm{nu}$ mice. The tumor volumes were calculated using the following formula: Volume $=4 / 3 \times \pi \times(1 / 2 \times$ smaller diameter $)^{2} \times 1 / 2 \times$ larger diameter. After euthanizing the mice, tumors, axillary lymph nodes, and lungs were removed from each mouse. The tissue was embedded in OCT compound or was snap frozen in liquid nitrogen. All animal studies were done according to the German ethical guidelines and the German laws for protection of animals.

\section{Inhibition ELISA}

Mice were intraperitoneally injected with N-TSP2-Fc $(100 \mu \mathrm{g} / 100 \mu \mathrm{l}$ PBS$)$. Serum samples were obtained at various times $(0,0.5,1,2,6,12$, and $24 \mathrm{~h})$ after injection. The concentration of TSP-2 was determined using an inhibition ELISA. 96-well plates (MaxiSorbTM, Nunc) were coated overnight with N-TSP2-Fc at a concentration of $1 \mu \mathrm{g} / \mathrm{ml}$. The remaining reactive sites were blocked with $1 \%$ BSA. A polyclonal goat antibody directed against the $\mathrm{N}$-terminal region of human TSP-2 (R\&D) was previously mixed in 96-well plates either with standard solutions of N-TSP2-Fc (ranging from $2 \mathrm{pg} / \mathrm{ml}$ to $20 \mu \mathrm{g} / \mathrm{ml}$ ) or with mouse serum to be tested that was diluted 1:50 and 1:500 with PBS. This mixture was added to the N-TSP2-Fccoated wells and incubated for $2 \mathrm{~h}$ at RT. The samples were assayed using a chemiluminescent substrate (SuperSignal ELISA Pico substrate). Luminescence was measured at $425 \mathrm{~nm}$ using a multi-detection microplate reader (BioTek Instruments GmbH). Data were analyzed using the SigmaPlot software (Systat Software), and the concentration of TSP-2 in each sample was calculated from the standard curve.

Analysis of tumor angiogenesis

Cryostat sections $(5 \mu \mathrm{m})$ were stained with a rat antimouse CD31 monoclonal antibody (BD Pharmingen). Representative sections obtained from five tumors were analyzed using an Olympus IX51 microscope. Images were captured and morphometric analyses were performed using the IP LAB software (Scanalytics) as described [45]. Three different fields in each section were examined at $10 \times$ magnification, and the number of vessels per $\mathrm{mm}^{2}$, the vessel size, and the relative area occupied by tumor blood vessels within the tumors were determined.

Quantitative analysis of metastasis

The DNEasy Blood and Tissue Kit (Qiagen) was used for isolation of genomic DNA. Primers (Eurogentec) specific for the human alu sequences (sense: $5^{\prime}$-CATGGTGAAAC CCCGTCTCTA- $3^{\prime}$; and antisense: $5^{\prime}$-GCCTCAGCCTCC CGAGTAG- $3^{\prime}$ ) were used to amplify human alu repeats present in genomic DNA that was extracted from mouse tissue. The internal TaqMan probe for alu (5'-[YY]-AT TAGCCGGGCGTGGTGGC-[BHQ-1]-3') was $5^{\prime}$-labeled with the reporter fluorescent dye Yakima Yellow (YY) and carried the non-fluorescent quencher dye Black Hole Quencher-1 (BHQ-1). The 18S rRNA control kit (Eurogentec) was used as an internal reference and was labeled with the reporter dye 6-carboxy-fluorescein (FAM) at the $5^{\prime}$ end and the quencher dye 6-carboxy-tetramethyl-rhodamin (TAMRA) at the $3^{\prime}$ end. PCRs were carried out in $25 \mu \mathrm{l}$ using $2 \times$ TaqMan Universal PCR Master Mix (Applied Biosystems), $0.9 \mu \mathrm{M}$ each alu specific oligonucleotide primer, $250 \mathrm{nM}$ internal alu probe, $1.5 \mu \mathrm{l} 18 \mathrm{~S}$ rRNA primer mix, $0.5 \mu \mathrm{l}$ internal $18 \mathrm{~S}$ rRNA probe, and $1 \mu \mathrm{l}$ genomic DNA. The final concentration for genomic DNA was $5 \mathrm{ng} / \mu \mathrm{l}$ for lymph node tissue and $50 \mathrm{ng} / \mu \mathrm{l}$ for lung tissue. PCR was carried out for $2 \mathrm{~min}$ at $50^{\circ} \mathrm{C}$ and for $10 \mathrm{~min}$ at $95^{\circ} \mathrm{C}$ followed by 40 cycles of $15 \mathrm{~s}$ at $95^{\circ} \mathrm{C}$ and $1 \mathrm{~min}$ at $60^{\circ} \mathrm{C}$ using the ABI PRISM ${ }^{\mathrm{TM}} 7700$ Sequence Detector (Applied Biosystems). Serial dilution steps (1:10) of genomic DNA obtained from human MDA-MB-435 cells in genomic DNA were obtained from 
either mouse lymph node or lung tissue served to construct the calibration curves. The cycle at which the alu PCR product becomes detectable above background signal $\left(\mathrm{Ct}_{\text {alu }}\right)$ was determined for each dilution series. The alu signal was normalized against the relative quantity of $18 \mathrm{~S}$ rRNA and expressed as $\Delta \mathrm{Ct}=\mathrm{Ct}_{\text {alu }}-\mathrm{Ct}_{18 \text { SrRNA }}$. A standard curve was generated for each measurement by using the real-time PCR assay and by plotting $\Delta \mathrm{Ct}$ as a function of the relative amount of human DNA in murine DNA (\%). The $R^{2}$ value (correlation coefficient) was $>0.96$ for all measurements demonstrating an excellent relationship between the alu signal and the relative amount of human DNA with a detection limit of $0.001 \%$ human DNA in murine DNA.

\section{Statistical analysis}

The two-sided unpaired t-test was used to analyze the tumor and metastasis data and to analyze the differences in microvessel density, vessel size, and total vascular area. Tube formation, apoptosis, mitochondrial membrane potential, and caspase-3 activity were analyzed for significant differences by one-way ANOVA followed by Student-Newman-Keuls' test for comparison of individual groups, after a Bartlett test had shown that variances were homogenous.

\section{Results}

N-TSP2-Fc inhibits tube formation of CD36 positive endothelial cells

Puromycin-selected human 293-EBNA cell clones secreting high amounts of N-TSP2-Fc were used for large-scale expression. The molecular weight of the purified recombinant protein was determined as approximately $110 \mathrm{kDa}$ by SDS-PAGE followed by western blot (data not shown). $\mathrm{N}$-terminal amino acid sequence analysis confirmed that the recombinant protein included amino acid 18-550 of human TSP-2 containing the heparin-binding-domain, the procollagen-like domain, and the three type 1 (properdinlike) repeats. The antiangiogenic efficacy was analyzed by investigating the effect of N-TSP2-Fc on VEGF-induced tube formation of HDMEC cultured on matrigel. After $12 \mathrm{~h}$, formation of networks with interconnection of tubelike structures was detected in HDMEC culture (Fig. 1a). In contrast, only sparse tube-like structures were detected when HDMEC were treated with N-TSP2-Fc (Fig. 1c) resulting in a significant reduction of the average tube length by more than $50 \%$ (Fig. 1e). After incubation of HDMEC with blocking CD36 antibody addition of $\mathrm{N}-\mathrm{TSP} 2-\mathrm{Fc}$ resulted in tube formation that was comparable to untreated control (Fig. 1d, e) demonstrating that
Fig. 1 N-TSP2-Fc inhibits HDMEC tube formation on Matrigel in a CD36-dependent manner. HDMEC were seeded on Matrigel in the presence of VEGF. Cultures were treated with either PBS (a), or IgG-Fc (b), or N-TSP2-Fc (c). In d HDMEC were incubated with both N-TSP2-Fc and blocking CD36 antibody (CD36 ab). $($ Bar $=200 \mu \mathrm{m})$. Quantitative image analysis of tube length (e) revealed that treatment with N-TSP2-Fc significantly reduced the average tube length as compared to control-treated HDMEC. After preincubation of HDMEC with a blocking CD36 antibody (CD36 ab) the average tube length was comparable in $\mathrm{N}-\mathrm{TSP} 2-\mathrm{Fc}$ - and control-treated HDMEC. Treatment with IgGFc did not have any significant effects on the average tube length. Data are expressed as mean $\pm \operatorname{SEM}(n=3)$. *** $P<0.001$
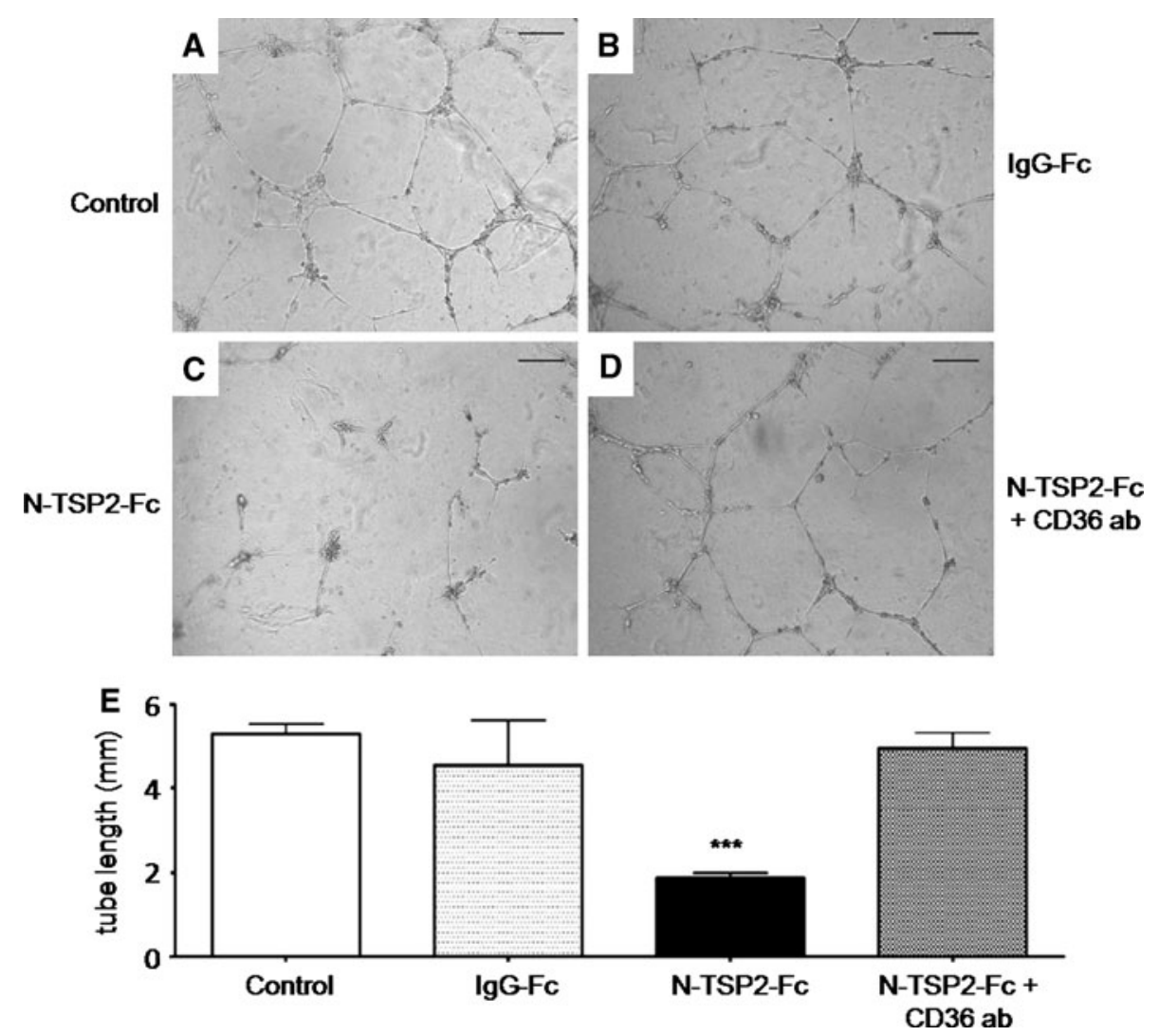
activation of the CD36 receptor was involved in the pronounced inhibition of network formation by N-TSP2-Fc. Treatment of HDMEC with IgG-Fc did not show any significant effect on VEGF-induced network formation providing evidence that the $\mathrm{Fc}$ fragment is not involved in the antiangiogenic activity of N-TSP2-Fc (Fig. 1b, e).

N-TSP2-Fc induces activation of apoptosis in microvascular endothelial cells

Flow cytometry of the sub- $\mathrm{G}_{1}$ apoptotic population showed that treatment of HDMEC with N-TSP2-Fc for $72 \mathrm{~h}$ in the presence of VEGF resulted in a significant increase of apoptotic endothelial cells by more than $45 \%$ as compared to control-treated cells (Fig. 2a). Parallel incubation with blocking CD36 antibody attenuated N-TSP2-Fc-induced apoptosis in HDMEC to close to the basal level indicating that CD36 is required for the apoptotic activity of N-TSP2Fc (Fig. 2a).

N-TSP2-Fc causes activation of caspase-3 and of the mitochondrial-dependent intrinsic pathway of apoptosis

Treatment of HDMEC with N-TSP2-Fc for $72 \mathrm{~h}$ resulted in a significant loss of mitochondrial membrane potential and decreased the mitochondrial membrane potential to $66 \%$ of control $(=100 \% ; P<0.001)$. When HDMEC were treated with CD36 blocking antibody, addition of N-TSP2-Fc failed to induce loss of mitochondrial membrane potential (Fig. 2b). In addition, treatment of HDMEC with N-TSP2Fc for $72 \mathrm{~h}$ significantly induced activation of caspase- 3 by more than $100 \%$ as compared to PBS control (Fig. 2c, d). The activation of caspase- 3 by N-TSP2-Fc was almost
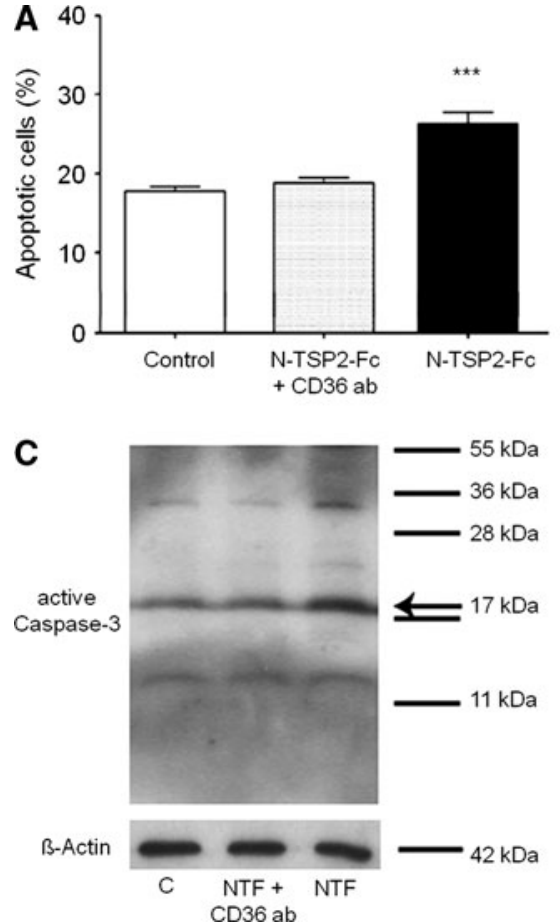

Fig. 2 N-TSP2-Fc induces apoptosis of HDMEC by CD36 receptormediated loss of mitochondrial membrane potential and activation of caspase-3. Percentage of apoptotic HDMEC (a) was measured by flow cytometry. Treatment with N-TSP2-Fc resulted in a significant increase of HDMEC apoptosis (a). Concurrent addition of a blocking CD36 antibody (CD36 ab) with N-TSP2-Fc inhibited this effect (a). The percentage of mitochondrial membrane potential (b) was decreased after treatment of HDMEC with N-TSP2-Fc. Simultaneous incubation of N-TSP2-Fc with anti-CD36 antibody (CD36 ab) did not induce loss of mitochondrial membrane potential when compared to control HDMEC (b). Active caspase-3 was analyzed in HDMEC by
B
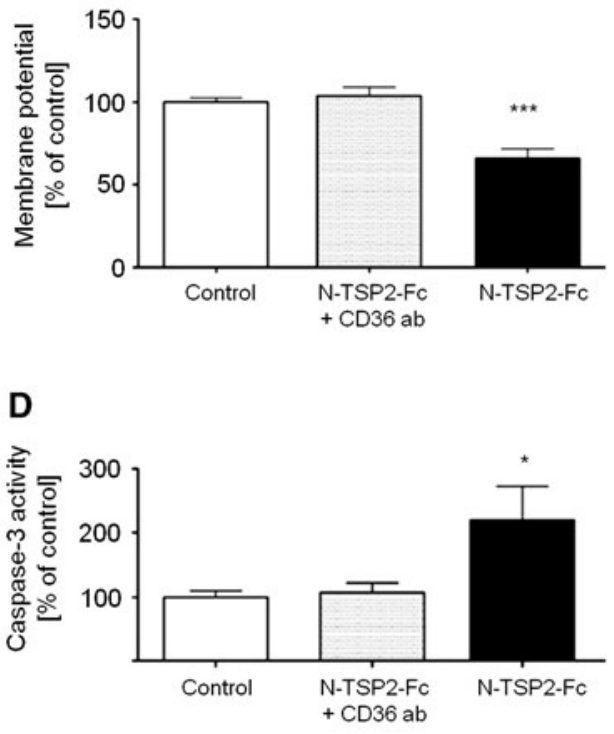

western blot analysis (c). Image analysis (d) of the bands revealed that caspase-3 activity was increased by incubation of HDMEC with N-TSP2-Fc. Caspase-3 activity of control-treated HDMEC or HDMEC incubated with N-TSP2-Fc and concurrent addition of anti-CD36 antibody (CD36 ab) was comparable (d). In all experiments a-d, HDMEC were incubated with PBS (control), or with $40 \mu \mathrm{g} / \mathrm{ml}$ of $\mathrm{N}$ TSP2-Fc, or with $40 \mu \mathrm{g} / \mathrm{ml}$ of N-TSP2-Fc plus $10 \mu \mathrm{g} / \mathrm{ml}$ of blocking CD36 antibody. All experiments were performed in the presence of VEGF $(20 \mathrm{ng} / \mathrm{ml})$. Results are expressed as mean $\pm \operatorname{SEM}(n=3)$. ** $P<0.01, * * * P<0.001$ 
completely abrogated by parallel incubation of HDMEC with blocking CD36 antibody (Fig. 2c, d).

Systemic treatment with N-TSP2-Fc inhibits tumor growth and angiogenesis

MDA-MB-435 tumor cells were subcutaneously injected into the second mammary gland of nude mice. Six days after tumor cell injection mice received either vehicle control (PBS), IgG-Fc (5 mg/kg/day), or N-TSP2-Fc $(5 \mathrm{mg} / \mathrm{kg} /$ day $)$. Control-treated mice formed tumors reaching a volume of $\sim 600 \mathrm{~mm}^{3}$ within 21 days (Fig. 1S). Following systemic treatment with N-TSP2-Fc for 15 days, MDA-MB-435 tumors reached a volume of $\sim 220 \mathrm{~mm}^{3}$, representing a $63 \%$ inhibition of tumor growth $(P<0.001$; Fig. 1S). At this time point, treatment with $\mathrm{IgG}-\mathrm{Fc}$ did not result in any major difference of tumor growth as compared to control mice $(P=0.39$; Fig. $1 \mathrm{~S})$. We next investigated whether the prolongation of the growth period might change the inhibitory effect on tumor growth by N-TSP2-Fc ( $5 \mathrm{mg} / \mathrm{kg}$ body weight) treatment. After a growth period of 36 days the experiment had to be terminated due to tumor burden and first signs of tumor ulceration in the control group according to the institutional regulations on animal experiments. Systemic treatment was initiated 6 days after tumor cell injection and continued daily for 30 days. The inhibitory effect of N-TSP2-Fc became highly significant at day 22 of MDA-MB-435 tumor growth and was maintained until the end of the growth period resulting in a $61 \%$ inhibition of tumor growth at day 36, compared to controltreated tumors $(P<0.001$; Fig 3a). To analyze tumorassociated vascularization frozen sections of MDA-MB435 tumors were stained for the endothelial junction molecule CD31 [13]. Computer-assisted morphometric image analysis revealed that both the vessel density (Fig. 3b) and the average vessel size (Fig. 3c) was significantly decreased in N-TSP2-Fc-treated tumors, as compared with control tumors, resulting in a significant decrease in the relative area occupied by tumor vessels by $67 \% \quad(P<0.001$; Fig. 3d). To determine the serum concentration of both TSP-2 and N-TSP2-Fc we established an inhibition ELISA using an antibody directed against the $\mathrm{N}$-terminal region of TSP-2. The serum concentration of TSP-2 in untreated tumor-bearing mice was $28.4 \pm 3.6 \mathrm{ng} / \mathrm{ml}$ (Table 1). Intraperitoneal administration of N-TSP2-Fc resulted in an increase of the serum concentration of TSP-2 and this effect lasted up to $24 \mathrm{~h}$. Since intraperitoneal injection of PBS did not result in any major differences in the serum concentration of TSP-2 (data not shown) the observed higher level of serum TSP-2 is due to an increase of the concentration of recombinant N-TSP2-Fc. As early as $30 \mathrm{~min}$ after intraperitoneal injection we found a strong increase in the serum level of N-TSP2-Fc (Table 1) that reached a peak at $1 \mathrm{~h}$ after intraperitoneal injection. Afterward the serum

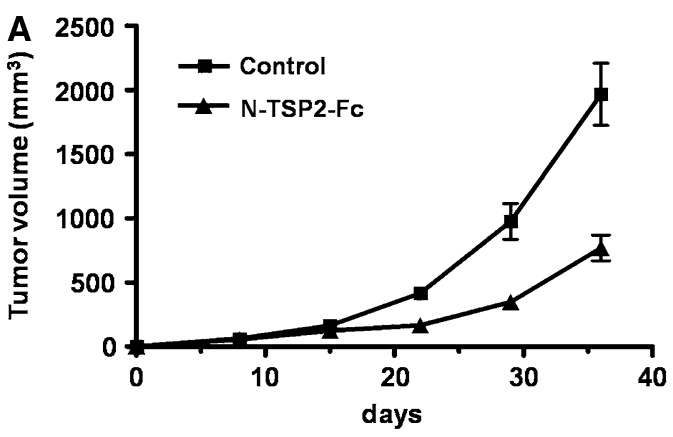

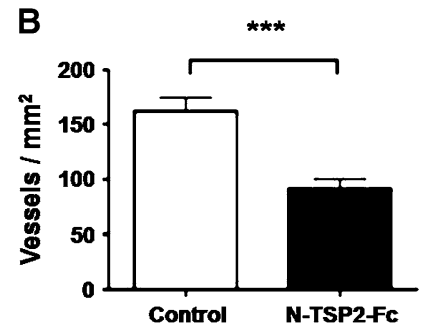

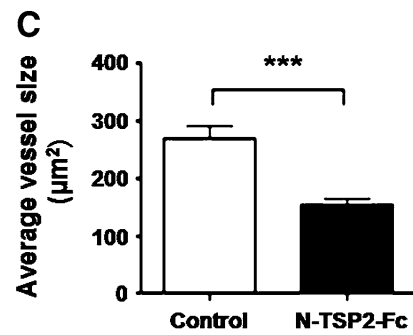

D

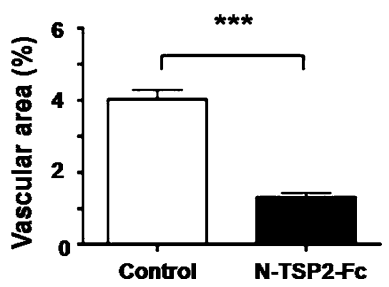

Fig. 3 Systemic treatment with N-TSP2-Fc inhibits in vivo growth and angiogenesis of MDA-MB-435 tumors grown in the mammary gland. PBS (control) or $5 \mathrm{mg}$ per kg body weight of N-TSP2-Fc were daily injected intraperitoneally, beginning at day 6 after tumor cell implantation. MDA-MB-435 tumor growth was inhibited by treatment with N-TSP2-Fc as compared with PBS control treatment (a). Computer-assisted image analysis of CD31-stained cryostat tumor sections revealed a significant reduction of the number of blood vessels per $\mathrm{mm}^{2}$ tumor area (b), of the average vessel size (c), and of the relative tumor area covered by blood vessels (d) in mice treated with N-TSP2-Fc. CD31-stained blood vessels were evaluated in three different $\times 10$ fields in sections obtained from five different tumors for each treatment group. Data are expressed as mean + SEM. $* * * P<0.001$ 
Table 1 Intraperitoneal injection of N-TSP2-Fc results in increased serum level of TSP-2

\begin{tabular}{ll}
\hline $\begin{array}{l}\text { Time (h) after } \\
\text { injection (i.p.) }\end{array}$ & $\begin{array}{l}\text { Serum concentration } \\
\text { of TSP-2 }\end{array}$ \\
\hline 0 & $0.0284 \pm 0.0036 \mu \mathrm{g} / \mathrm{ml}$ \\
0.5 & $16.8 \pm 1.8 \mu \mathrm{g} / \mathrm{ml}$ \\
1.0 & $19.7 \pm 3.8 \mu \mathrm{g} / \mathrm{ml}$ \\
6.0 & $0.198 \pm 0.053 \mu \mathrm{g} / \mathrm{ml}$ \\
12.0 & $0.179 \pm 0.043 \mu \mathrm{g} / \mathrm{ml}$ \\
24.0 & $0.029 \pm 0.0063 \mu \mathrm{g} / \mathrm{ml}$
\end{tabular}

After intraperitoneal injection of $100 \mu \mathrm{g}$ of N-TSP2-Fc diluted in $100 \mu \mathrm{l}$ PBS, serum levels of TSP-2 were measured by an inhibition ELISA using an antibody directed against the $\mathrm{N}$-terminal region of TSP2. Data revealed that serum concentration of TSP-2 rapidly increased $(0.5 \mathrm{~h})$ and reached a peak at $1 \mathrm{~h}$ after intraperitoneal injection. The serum concentration of TSP- 2 was increased for $24 \mathrm{~h}$

concentration of N-TSP2-Fc rapidly decreased at $12 \mathrm{~h}$ after injection and reached a serum concentration that was close to the TSP-2 level of untreated tumor-bearing mice at $24 \mathrm{~h}$ after intraperitoneal administration (Table 1). In addition, we examined the effect of recombinant N-TSP2-Fc on in vivo tumor growth of orthotopically injected MDA-MB231 breast cancer cells (Fig. 2S). One week after tumor cell injection, mice were treated daily either with N-TSP2-Fc ( $5 \mathrm{mg} / \mathrm{kg}$ body weight) or vehicle control. Four weeks after tumor cell injection systemic treatment with N-TSP2-Fc resulted in a significant inhibition of xenotransplanted

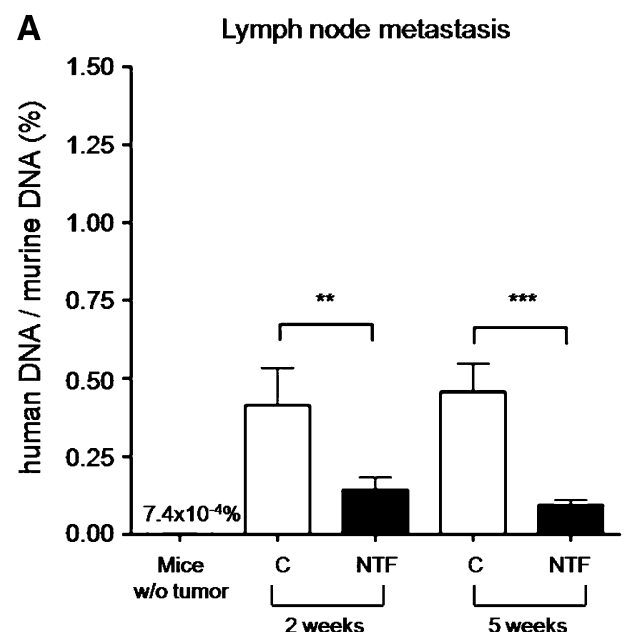

Fig. 4 N-TSP2-Fc inhibits lymph node and lung metastasis. Quantitative real-time PCR was used to analyze human alu repeats from MDA-MB-435 tumor cells present in genomic murine DNA that was extracted from lymph node (a) and lung tissue (b). Lymph node (a) and lung (b) metastasis were analyzed at two and 5 weeks after tumor cell implantation in mice treated either with PBS (control; $n=10$ ) or N-TSP2-Fc (NTF; $n=10$ ). To measure the background signal in murine lymph node and lung tissue, quantitative real-time alu PCR was performed in non-tumor-bearing mice (mice w/o tumor). Data revealed an increase of the percentage of human DNA in murine
MDA-MB-231 breast carcinomas as compared to controltreated tumors $(P<0.05$; Fig. $2 S)$.

Systemic treatment with N-TSP2-Fc decreases metastasis

Results of alu PCR indicated the presence of human DNA as early as 2 weeks after tumor cell injection in both lymph node and lung tissue of tumor-bearing mice treated with vehicle control (Fig. 4a, b). The relative amount of human DNA in murine DNA at this time point was $0.41 \%$ in lymph node tissue and $0.024 \%$ in lung tissue of tumorbearing mice as compared to the background signal of $7.4 \times 10^{-4}$ and $4.2 \times 10^{-3} \%$ in non-tumor-bearing mice, respectively (Fig. 4a, b). Treatment of tumor-bearing mice with N-TSP2-Fc resulted in a significant reduction of both lymph node and lung metastasis at 2 weeks after tumor implantation (Fig. 4a, b). At 5 weeks after tumor cell injection the relative amount of human tumor DNA was reduced by $80 \%$ in lymph node tissue and by $68 \%$ in lung tissue of N-TSP2-Fc-treated mice as compared to control mice (Fig. 4a, b).

\section{Discussion}

TSP-2 is a potent endogenous inhibitor of tumor growth and angiogenesis $[17,45]$. The antitumoral effect of TSP-2

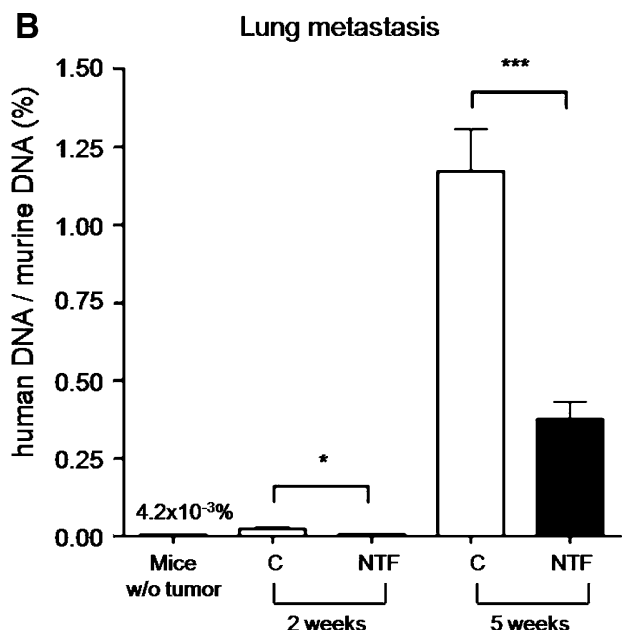

DNA obtained from lymph node and lung tissue of tumor-bearing mice at two and 5 weeks after tumor cell transplantation when compared to mice without tumors indicating the metastatic spread of MDA-MB-435 tumor cells to the lymph nodes and lung. Treatment with N-TSP2-Fc resulted in a significant reduction of the percentage of human DNA in murine DNA obtained from lymph node and lung tissue at two and 5 weeks after transplantation of MDA-MB-435 tumor cells in the mammary gland of nude mice. Values represent mean + SEM. $* P<0.05, * * P<0.01, * * * P<0.001$ 
is stronger than the effect of TSP-1 [45]. However, the exact molecular mechanism of the antiangiogenic activity of TSP-2 has not been as well studied as that of TSP-1. TSP-2 shows only low sequence homology to TSP-1 in the procollagen region. Moreover, a recombinant fragment of human TSP-2 that only included the N-terminal globular domain and the procollagen homology domain failed to significantly inhibit tumor growth and angiogenesis [34]. Therefore, the antiangiogenic activity of TSP-2 might map to the properdin-like type 1 repeats [46], which have been implicated in the antiangiogenic activity of TSP-1 [12, 20, 49]. The antiangiogenic effects within the properdin-like type 1 repeats of TSP-1 are mediated partly through interaction of the CSVTCG sequence with the CD36 receptor on endothelial cells $[11,21,46]$.

We produced a recombinant fusion protein, N-TSP2-Fc, that encompasses the $\mathrm{N}$-terminal globular region with all three type 1 repeats containing two CSVTCG sequence motifs within the first and second type 1 repeats. N-TSP2$\mathrm{Fc}$ exerted potent antiangiogenic activity in vitro. We found that N-TSP2-Fc significantly inhibited HDMEC tube formation and induced HDMEC apoptosis. N-TSP2-Fc also resulted in a significant increase of caspase- 3 activity and a significant loss of mitochondrial membrane potential in cultured HDMEC. Moreover, blockade of the CD36 receptor almost completely abrogated the reported in vitro effects of N-TSP2-Fc, strongly suggesting that the antiangiogenic activity of N-TSP2-Fc is mediated by CD36dependent induction of endothelial cell apoptosis and at least in part through activation of the intrinsic apoptotic pathway. This is in agreement with the previously reported binding of TSP-2 to CD36 and lack of inhibition of angiogenesis by TSP-2 in CD36 null mice [43]. The exact molecular mechanisms through which TSP-2 and TSRs induce activation of caspase- 3 and promote CD36-mediated apoptosis remain to be elucidated.

We investigated the efficacy of systemic therapy with $\mathrm{N}-\mathrm{TSP} 2-\mathrm{Fc}$ on both tumor growth and metastasis. To this end we made use of MDA-MB-435 tumor cells representing a well-established orthotopic model system for the study of breast cancer metastasis. MDA-MB-435 cells form primary tumors when injected into the mammary fat pad of nude mice, and spontaneously metastasize from these tumors to the lymph nodes and lungs [37, 44, 52]. However, in a microarray expression study MDA-MB-435 cells have been reported to cluster with several melanoma cell lines [39], and it has been speculated that that MDA-MB-435 cell is instead the M14 melanoma cell line, due to an early cross-contamination of cell cultures [9, 38]. MDA-MB-435 cells have been shown to express melanocytic proteins [42] as well as epithelial markers such as cytokeratin 19 and secrete milk proteins and lipids [42] suggesting that MDAMB-435 breast cancer cells may have undergone a lineage infidelity during tumor progression [42]. Indeed, lineage infidelity has been seen in breast carcinomas that express both epithelial and melanoma-associated proteins [33, 35]. Very recently, Chambers [9] reported that although currently available stocks of the MDA-MB-435 and M14 cell lines were shown to be virtually identical at the karyotype level [38], the conclusion that M14 and MDA-MB-435 cells are of M14 melanoma origin is inconsistent with the fact that the M14 cell line derived from a male patient with metastatic melanoma [10] and the female karyotypes of both cell lines at present $[9,38]$. Chambers [9] suggested that the evidence from the literature rather is consistent with cell lines being of MDA-MB-435 breast cancer origin and that the MDA-MB-435 cell line represents a poorly differentiated aggressive breast tumor line with expression of both epithelial and melanocytic markers. In addition, in a recent study on distinct gene mutation profiles among luminal-type and basal-type breast cancer cell lines Hollestelle et al. [19] revealed that the MDA-MB-435 cell line was basal-type. They identified subtype-specific gene mutation profiles revealing that basal-type breast cancers may have a genetic basis similar to melanomas [18, 19]. Hollestelle et al. concluded conclusively that MDA-MB435 is a breast cancer cell line [18].

We provide strong evidence that intraperitoneally injected N-TSP2-Fc sufficiently reached the blood circulation as shown by an inhibition ELISA and thereby systemically inhibited MDA-MB-435 tumor progression due to an inhibition of angiogenesis. We could also demonstrate that IgG-Fc did not have any major effects on MDAMB-435 tumor growth in vivo. In addition, the inhibitory effect of recombinant N-TSP2-Fc on the growth of breast carcinomas could be confirmed by using of another, MDAMB-231 [7], breast cancer cell line. Systemic treatment with N-TSP2-Fc also resulted in a significant inhibition of xenotransplanted MDA-MB-231 breast cancer cells. Our findings are consistent with recently reported growth inhibition of xenotransplanted A431 squamous cell carcinomas by intraperitoneal application of a recombinant TSP-2 protein that include TSR sequences [34]. We have combined the accuracy and sensitivity of real-time PCR [30] with the human specificity of alu sequences [40, 48, 54] for direct quantitative evaluation of metastatic MDAMB-435 breast cancer cells in lymph nodes and lungs. As early as 2 weeks after tumor cell injection we could detect human tumor cell DNA in lymph node and lung tissue of MDA-M-435 breast tumor-bearing mice. The amount of human DNA in the lungs was much lower than that in the lymph nodes, indicating that lymph node metastasis is an earlier event than distant lung metastasis. This is consistent with the clinical course of most breast cancer diseases [4, 31]. We also found significantly less human tumor cell DNA in the lymph nodes and lungs of N-TSP2-Fc-treated 
mice as compared to control-treated mice. The inhibitory effect on metastasis was maintained over the entire period of in vivo tumor growth. Even at 5 weeks after tumor cell inoculation, both lymph node and lung metastasis were significantly reduced in N-TSP2-Fc-treated mice.

Controversial findings have been reported regarding the effects of TSP-1 on metastasis [2,3] [47] [51]. Recent in vitro $[2,5]$ and in vivo [53] data suggest that prometastatic effects of endogenous TSP-1 may involve the activation of transforming growth factor- $\beta$ (TGF- $\beta$ ) via the unique sequence KRFK found between the first and second type 1 repeats of TSP-1 [41]. Noteworthy, TSP-2 lacks the KRFK sequence, and recent studies have not found any evidence for activation of latent TGF- $\beta$ by TSP-2 [26]. Whether the lack of TGF- $\beta$ activation may explain the lack of any reported prometastatic effect of TSP-2 remains to be further evaluated. In support of this hypothesis are recent findings demonstrating that lymph node metastasis was only observed in TSP-2-null mice but not in wild-type mice in a multistep chemically induced skin carcinogenesis protocol [17] whereas in a transgenic mouse model of breast cancer pulmonary metastasis was increased in TSP-1 null mice as compared to wild-type mice [53]. Recently, preclinical studies reported that angiogenesis inhibitors targeting the VEGF signaling pathway reduced primary tumor growth but promoted tumor invasiveness and metastasis in vivo [14, 36]. Multi-targeting of parallel angiogenesis regulating pathways have been proposed to improve the benefits of antiangiogenic drug therapy [6]. Our results demonstrate that N-TSP2-Fc treatment potently inhibits both tumor growth and metastasis in vivo mediated by CD36-dependent inhibition of tumor angiogenesis, and they indicate its potential use for antiangiogenic combination therapies to treat breast cancer.

Acknowledgments We thank Renate Dietrich, Matthias Läsche, and Hiltrud Schulz for excellent technical assistance. This study was supported by Deutsche Forschungsgemeinschaft grants (HA 2898 4-1 and 4-2, MK SFB 832 A8).

\section{References}

1. Adams JC, Lawler J (2004) The thrombospondins. Int J Biochem Cell Biol 36:961-968

2. Albo D, Berger DH, Wang TN, Hu X, Rothman V, Tuszynski GP (1997) Thrombospondin-1 and transforming growth factor-beta 1 promote breast tumor cell invasion through up-regulation of the plasminogen/plasmin system. Surgery 122:493-499 (discussion 499-500)

3. Albo D, Rothman VL, Roberts DD, Tuszynski GP (2000) Tumour cell thrombospondin-1 regulates tumour cell adhesion and invasion through the urokinase plasminogen activator receptor. Br J Cancer 83:298-306

4. Alix-Panabieres C, Muller V, Pantel K (2007) Current status in human breast cancer micrometastasis. Curr Opin Oncol 19: $558-563$
5. Arnoletti JP, Albo D, Granick MS, Solomon MP, Castiglioni A, Rothman VL, Tuszynski GP (1995) Thrombospondin and transforming growth factor-beta 1 increase expression of urokinasetype plasminogen activator and plasminogen activator inhibitor-1 in human MDA-MB-231 breast cancer cells. Cancer 76:998-1005

6. Bergers G, Hanahan D (2008) Modes of resistance to antiangiogenic therapy. Nat Rev Cancer 8:592-603

7. Cailleau R, Young R, Olive M, Reeves WJ Jr (1974) Breast tumor cell lines from pleural effusions. J Natl Cancer Inst 53:661-674

8. Carmeliet P, Jain RK (2000) Angiogenesis in cancer and other diseases. Nature 407:249-257

9. Chambers AF (2009) MDA-MB-435 and M14 cell lines: identical but not M14 melanoma? Cancer Res 69:5292-5293

10. Chee DO, Boddie AW, Roth JA, Holmes EC, Morton DL (1976) Production of melanoma-associated antigen(s) by a defined malignant melanoma cell strain grown in chemically defined medium. Cancer Res 36:1503-1509

11. Dawson DW, Pearce SF, Zhong R, Silverstein RL, Frazier WA, Bouck NP (1997) CD36 mediates the In vitro inhibitory effects of thrombospondin-1 on endothelial cells. J Cell Biol 138:707-717

12. Dawson DW, Volpert OV, Pearce SF, Schneider AJ, Silverstein RL, Henkin J, Bouck NP (1999) Three distinct D-amino acid substitutions confer potent antiangiogenic activity on an inactive peptide derived from a thrombospondin-1 type 1 repeat. Mol Pharmacol 55:332-338

13. Dejana E, Corada M, Lampugnani MG (1995) Endothelial cellto-cell junctions. FASEB J 9:910-918

14. Ebos JM, Lee CR, Cruz-Munoz W, Bjarnason GA, Christensen JG, Kerbel RS (2009) Accelerated metastasis after short-term treatment with a potent inhibitor of tumor angiogenesis. Cancer Cell 15:232-239

15. Ferrara N, Kerbel RS (2005) Angiogenesis as a therapeutic target. Nature 438:967-974

16. Folkman J (1971) Tumor angiogenesis: therapeutic implications. N Engl J Med 285:1182-1186

17. Hawighorst T, Velasco P, Streit M, Hong YK, Kyriakides TR, Brown LF, Bornstein P, Detmar M (2001) Thrombospondin-2 plays a protective role in multistep carcinogenesis: a novel host anti-tumor defense mechanism. EMBO J 20:2631-2640

18. Hollestelle A, Schutte M (2009) Comment Re: MDA-MB-435 and M14 cell lines: identical but not M14 Melanoma? Cancer Res 69:7893

19. Hollestelle A, Nagel JH, Smid M, Lam S, Elstrodt F, Wasielewski M, Ng SS, French PJ, Peeters JK, Rozendaal MJ, Riaz M, Koopman DG, Ten Hagen TL, de Leeuw BH, Zwarthoff EC, Teunisse A, van der Spek PJ, Klijn JG, Dinjens WN, Ethier SP, Clevers H, Jochemsen AG, den Bakker MA, Foekens JA, Martens JW, Schutte M (2010) Distinct gene mutation profiles among luminal-type and basal-type breast cancer cell lines. Breast Cancer Res Treat 121:53-64

20. Iruela-Arispe ML, Lombardo M, Krutzsch HC, Lawler J, Roberts DD (1999) Inhibition of angiogenesis by thrombospondin-1 is mediated by 2 independent regions within the type 1 repeats. Circulation 100:1423-1431

21. Jimenez B, Volpert OV, Crawford SE, Febbraio M, Silverstein RL, Bouck N (2000) Signals leading to apoptosis-dependent inhibition of neovascularization by thrombospondin-1. Nat Med 6:41-48

22. Kazerounian S, Yee KO, Lawler J (2008) Thrombospondins in cancer. Cell Mol Life Sci 65:700-712

23. Kerbel RS (2008) Tumor angiogenesis. N Engl J Med 358:2039-2049

24. Koch M, Murrell JR, Hunter DD, Olson PF, Jin W, Keene DR, Brunken WJ, Burgeson RE (2000) A novel member of the netrin 
family, beta-netrin, shares homology with the beta chain of laminin: identification, expression, and functional characterization. J Cell Biol 151:221-234

25. Kyriakides TR, Zhu YH, Smith LT, Bain SD, Yang Z, Lin MT, Danielson KG, Iozzo RV, LaMarca M, McKinney CE, Ginns EI, Bornstein P (1998) Mice that lack thrombospondin 2 display connective tissue abnormalities that are associated with disordered collagen fibrillogenesis, an increased vascular density, and a bleeding diathesis. J Cell Biol 140:419-430

26. Kyriakides TR, Zhu YH, Yang Z, Huynh G, Bornstein P (2001) Altered extracellular matrix remodeling and angiogenesis in sponge granulomas of thrombospondin 2-null mice. Am J Pathol 159:1255-1262

27. Lawler J (2000) The functions of thrombospondin-1 and-2. Curr Opin Cell Biol 12:634-640

28. Lawler J, Sunday M, Thibert V, Duquette M, George EL, Rayburn H, Hynes RO (1998) Thrombospondin-1 is required for normal murine pulmonary homeostasis and its absence causes pneumonia. J Clin Invest 101:982-992

29. Miller K, Wang M, Gralow J, Dickler M, Cobleigh M, Perez EA, Shenkier T, Cella D, Davidson NE (2007) Paclitaxel plus bevacizumab versus paclitaxel alone for metastatic breast cancer. N Engl J Med 357:2666-2676

30. Mocellin S, Rossi CR, Pilati P, Nitti D, Marincola FM (2003) Quantitative real-time PCR: a powerful ally in cancer research. Trends Mol Med 9:189-195

31. Nakagawa T, Martinez SR, Goto Y, Koyanagi K, Kitago M, Shingai T, Elashoff DA, Ye X, Singer FR, Giuliano AE, Hoon DS (2007) Detection of circulating tumor cells in early-stage breast cancer metastasis to axillary lymph nodes. Clin Cancer Res 13:4105-4110

32. Nicoletti I, Migliorati G, Pagliacci MC, Grignani F, Riccardi C (1991) A rapid and simple method for measuring thymocyte apoptosis by propidium iodide staining and flow cytometry. J Immunol Methods 139:271-279

33. Nobukawa B, Fujii H, Hirai S, Kumasaka T, Shimizu H, Matsumoto T, Suda K, Futagawa S (1999) Breast carcinoma diverging to aberrant melanocytic differentiation: a case report with histopathologic and loss of heterozygosity analyses. Am J Surg Pathol 23:1280-1287

34. Noh YH, Matsuda K, Hong YK, Kunstfeld R, Riccardi L, Koch M, Oura H, Dadras SS, Streit M, Detmar M (2003) An N-terminal $80 \mathrm{kDa}$ recombinant fragment of human thrombospondin-2 inhibits vascular endothelial growth factor induced endothelial cell migration in vitro and tumor growth and angiogenesis in vivo. J Invest Dermatol 121:1536-1543

35. Padmore RF, Lara JF, Ackerman DJ, Gales T, Sigurdson ER, Ehya H, Cooper HS, Patchefsky AS (1996) Primary combined malignant melanoma and ductal carcinoma of the breast A report of two cases. Cancer 78:2515-2525

36. Paez-Ribes M, Allen E, Hudock J, Takeda T, Okuyama H, Vinals F, Inoue M, Bergers G, Hanahan D, Casanovas O (2009) Antiangiogenic therapy elicits malignant progression of tumors to increased local invasion and distant metastasis. Cancer Cell $15: 220-231$

37. Price JE, Polyzos A, Zhang RD, Daniels LM (1990) Tumorigenicity and metastasis of human breast carcinoma cell lines in nude mice. Cancer Res 50:717-721

38. Rae JM, Creighton CJ, Meck JM, Haddad BR, Johnson MD (2007) MDA-MB-435 cells are derived from M14 melanoma cells-a loss for breast cancer, but a boon for melanoma research. Breast Cancer Res Treat 104:13-19

39. Ross DT, Scherf U, Eisen MB, Perou CM, Rees C, Spellman P, Iyer $\mathrm{V}$, Jeffrey SS, Van de Rijn $\mathrm{M}$, Waltham $\mathrm{M}$,
Pergamenschikov A, Lee JC, Lashkari D, Shalon D, Myers TG, Weinstein JN, Botstein D, Brown PO (2000) Systematic variation in gene expression patterns in human cancer cell lines. Nat Genet 24:227-235

40. Schneider T, Osl F, Friess T, Stockinger H, Scheuer WV (2002) Quantification of human Alu sequences by real-time PCR-an improved method to measure therapeutic efficacy of anti-metastatic drugs in human xenotransplants. Clin Exp Metastasis 19:571-582

41. Schultz-Cherry S, Chen H, Mosher DF, Misenheimer TM, Krutzsch HC, Roberts DD, Murphy-Ullrich JE (1995) Regulation of transforming growth factor-beta activation by discrete sequences of thrombospondin 1. J Biol Chem 270:7304-7310

42. Sellappan S, Grijalva R, Zhou X, Yang W, Eli MB, Mills GB, Yu D (2004) Lineage infidelity of MDA-MB-435 cells: expression of melanocyte proteins in a breast cancer cell line. Cancer Res 64:3479-3485

43. Simantov R, Febbraio M, Silverstein RL (2005) The antiangiogenic effect of thrombospondin-2 is mediated by CD36 and modulated by histidine-rich glycoprotein. Matrix Biol 24:27-34

44. Skobe M, Hawighorst T, Jackson DG, Prevo R, Janes L, Velasco P, Riccardi L, Alitalo K, Claffey K, Detmar M (2001) Induction of tumor lymphangiogenesis by VEGF-C promotes breast cancer metastasis. Nat Med 7:192-198

45. Streit M, Riccardi L, Velasco P, Brown LF, Hawighorst T, Bornstein P, Detmar M (1999) Thrombospondin-2: a potent endogenous inhibitor of tumor growth and angiogenesis. Proc Natl Acad Sci USA 96:14888-14893

46. Tolsma SS, Volpert OV, Good DJ, Frazier WA, Polverini PJ, Bouck N (1993) Peptides derived from two separate domains of the matrix protein thrombospondin-1 have anti-angiogenic activity. J Cell Biol 122:497-511

47. Urquidi V, Sloan D, Kawai K, Agarwal D, Woodman AC, Tarin D, Goodison S (2002) Contrasting expression of thrombospondin-1 and osteopontin correlates with absence or presence of metastatic phenotype in an isogenic model of spontaneous human breast cancer metastasis. Clin Cancer Res 8:61-74

48. van der Horst EH, Leupold JH, Schubbert R, Ullrich A, Allgayer $\mathrm{H}$ (2004) TaqMan-based quantification of invasive cells in the chick embryo metastasis assay. Biotechniques 37:940-942, 944, 946

49. Vogel T, Guo NH, Krutzsch HC, Blake DA, Hartman J, Mendelovitz S, Panet A, Roberts DD (1993) Modulation of endothelial cell proliferation, adhesion, and motility by recombinant heparinbinding domain and synthetic peptides from the type I repeats of thrombospondin. J Cell Biochem 53:74-84

50. Volpert OV, Tolsma SS, Pellerin S, Feige JJ, Chen H, Mosher DF, Bouck N (1995) Inhibition of angiogenesis by thrombospondin-2. Biochem Biophys Res Commun 217:326-332

51. Weinstat-Saslow DL, Zabrenetzky VS, VanHoutte K, Frazier WA, Roberts DD, Steeg PS (1994) Transfection of thrombospondin 1 complementary DNA into a human breast carcinoma cell line reduces primary tumor growth, metastatic potential, and angiogenesis. Cancer Res 54:6504-6511

52. Welch DR (1997) Technical considerations for studying cancer metastasis in vivo. Clin Exp Metastasis 15:272-306

53. Yee KO, Connolly CM, Duquette M, Kazerounian S, Washington R, Lawler J (2009) The effect of thrombospondin-1 on breast cancer metastasis. Breast Cancer Res Treat 114:85-96

54. Zijlstra A, Mellor R, Panzarella G, Aimes RT, Hooper JD, Marchenko ND, Quigley JP (2002) A quantitative analysis of rate-limiting steps in the metastatic cascade using human-specific real-time polymerase chain reaction. Cancer Res 62:7083-7092 